\title{
Kadın Sporcuların Sporu Seçme Nedenleri
}

\author{
Nimet HAŞIL KORKMAZ ${ }^{1}$, Gülşah Nur ŞEN ${ }^{2}$, Çiğdem GÖKDUMAN ${ }^{3 *}$, Fatma DEMİR ${ }^{4}$, \\ Simara Aybike UÇAR ${ }^{5}$
}

${ }^{1}$ Uludağ Üniversitesi, Spor Bilimleri Fakültesi,0000-0001-7648-3289

${ }^{2}$ Uludağ Üniversitesi, Eğitim Bilimleri Enstitüsü, 0000-0002-5669-350X

${ }^{3}$ Uludağ Üniversitesi, Eğitim Bilimleri Enstitüsü, 0000-0003-3104-2409

${ }^{4}$ MEB, Yalova, 0000-0002-6484-7329

${ }^{5}$ Uludağ Üniversitesi, Eğitim Bilimleri Enstitüsü,0000-0002-0618-3522

Orijinal Makale

Gönderi Tarihi: 27.03.2019
Kabul Tarihi: 02.06.2019
DOI: $10.30769 /$ usbd.545781

Online Yayın Tarihi: 30.06.2019

\section{$\ddot{O} z$}

Bu araştırmada Bursa ilinde 11 ayrı branștaki maskülen spor ile uğraşan kadın sporcuların maskülen branşları seçmelerinin sebeplerini araştırmak ve bu sporcuların cinsiyet rollerinin yaptıkları spor branşına etkilerini incelemek amaçlanmıştır. Araştırmanın çalışma evrenini maskülen spor branşlarıyla ilgilenen 18-25 yaş arası 90 kadın sporcu oluşturmaktadır. Araştırmada maskülen spor branşlarıyla ilgilenen kadın sporculara Anket Formu ile birleştirilmiş BEM Cinsiyet Rolü Envanteri uygulanmıştır. Araştırmada toplanan veriler SPSS 18.0 programı kullanılarak analiz edilmiştir. Verilerin analizinde OneWayAnova (Tek Yönlü Varyans) ve Crosstabs (Ki Kare) testi kullanılmıştır. Anket sorularında yaş durumu ve yaptığınız spor branşını seçme nedeni, değişkenlerine göre dağılım durumunda Crosstabs (Ki Kare) testi sonuçlarında, 14-17 yaş grubu toplam katılım sayısı 44 kişidir. Bem Cinsiyet Rolünün katılımcıların "Ailenizde sporla uğraşan var mı?” değișkeni OneWayAnova testi sonuçlarına göre ailede spor yapan kişilerin cinsiyet rolleri bakımından karşılaştırıldığında erkeksi cinsiyet rolü grubunda anlamlı bir fark görülmektedir. Katılımcıların "Spora başlamanızda kimler etkili oldu" değişkenine göre BEM Cinsiyet Rolü Puanı katılımcıların spora başlamasında etkili olan kişilerin cinsiyet rolleri üzerinde etkileri karşılaştırıldığında erkeksi grubunda anlamlı bir fark olduğu görülmektedir. Nitekim spor branşlarının erkeksi ve kadınsı olarak algılanması, sporda var olan fiziksel aktiviteler kadar, o sporlara katılan kişinin cinsiyetinden de etkilenir Sonuç olarak erkeklerin yoğunlukta olduğu spor dallarında kadın sporcular, kadınların yoğunlukta olduğu spor dallarında erkek sporcular toplumun zihinsel dönüşümüne aracılık edebilecek roldedirler.

Anahtar kelimeler: Spor, cinsel kimlik, maskülen, feminen.

\section{Why choose the sport of female athletes}

\begin{abstract}
The aim of this study was to investigate the reasons of female athletes in masculine sports in Bursa and to investigate the effects of gender roles on sports branches. The universe of the study consists of 90 female athletes between 18-25 years of age who are interested in masculine sports branches. In the research, female athletes interested in masculine sports branches were applied BEM Gender Role Inventory combined with the questionnaire. Data collected in the study were analyzed using SPSS 18.0 program. One-way ANOVA and Crosstabs test were used to analyze the data. Age Reason in the survey questions and the reason for choosing the sport branch? In the Crosstabs (Chi-Square) test results, the total number of participants in the 14-17 age group is 44. According to the One Way Anova test results of the Bem Gender Role, the participants of the Gender Role play a significant difference in the masculine gender role group. According to the participants who were effective in getting started with sports gender, BEM Gender Role Score was found to be a significant difference in the masculine group when the effects of the participants on the gender roles were compared. As a matter of fact, the perception of sports branches as masculine and feminine is affected by the physical activities of the sport as well as the gender of the person participating in those sports.
\end{abstract}

Keywords: Spor, sexual identity, masculine, feminine. 


\section{GíRIş}

Birey bir toplum içinde yaşamını barındırır. İlk kez karşılaştığı topluluk ise ailedir. Sosyalleşme aile ile başlar devamında okul ve arkadaş çevresi ile bir sıra izler (Göktepe, 2008). Birey ilk öğrenmelerini ailede kazanır. Bu öğrenmelere cinsiyet rolleri de dâhildir. Cinsiyet rollerin kazanımı kalıtsal gibi gözükse de çevrenin payı oldukça fazladır. Bireyin ilk örnek aldığı kişiler anne ve babaları daha sonra sosyalleştiği okul çevresidir. Toplumsal cinsiyet ile ilgili bilgiler çocukluktan başlar ve yetişkinliğe kadar devam eder. Birey 20- 25 aylık iken yakın çevresinde yetişkinlerin fiziksel görünüşleri ve cinsiyetlerini ayırt etmeye başlar. 3 yaşına yaklaşan bireyin oyuncaklarında farklılaşmalar gözlemlenir. Oynadıkları oyunları kız ve erkek oyunu diye ikiye ayırır. 5-6 yaşına geldiğinde ise cinsiyet ve kişiliği ilişkilendirmeye başlar. Artık toplumun kadın ve erkek cinsiyetine yüklediği anlamları fark etmeye başlar. Erkeklerin daha saldırgan ve atik olduğunu, kızların ise ev işlerini yapan, yardımsever kişilik özelliğine sahip bireyler olarak ayırt etmeye başlar (Çetin, 2009). Başta aileler sonra toplum olarak kızlar, kadınlara uygun fiziksel oyunlara veya aktivitelere yönlendirilirken erkek çocuklar, erkeklere uygun fiziksel aktivitelere yönlendirilir. Tercih ettikleri spor dallarına yönelimlerinde de bunları gözlemleyebiliriz. Ancak durum böyle olduğunda sporun temelinde bireyin cinsiyet, yaş, statü gibi ayrım yapılmaksızın yeteneklerinin sergileme ve gönül işi olduğu göz ardı edilmektedir(Yetim, 2006).

\section{Toplumsal Cinsiyet Rolleri ve Spor}

Kız ya da erkek her çocuk hem anne hem de baba ile özdeşim kurarak büyür. Yaşamın ilk üç yılında gerçekleşmesi gereken birçok psikolojik temelli işler bulunmaktadır. Bunlardan en önemlisi çekirdek bir kimlik oluşturma sürecidir (Direk, 2014).Üç yaşlarında olan bir çocuk birey olma yolunda birçok özelliği kazanmaya ve 'Ben Kimim?' sorusuna cevap aramaya başlar. Erkek çocuk maskülen bir kimlik kazanmak için anneden ayrılır ve babayla özdeşim kurarken, kız çocukları ise feminen bir kimlik oluşturmak için annesi ile özdeşim kurar. Burada önemli olan anne ve babanın çocuk ile iletişimidir. İlk model olarak gördüğü bireyler en yakını olan anneleri ve babalarıdır.

Toplumun, kadınlar ve erkeklerin göstermelerini beklediği özelliklere toplumsal kalıp yargılar denilmektedir (Şirvanlı-Özen ve Bayraktar, 1993). Kadın ve erkek pek çok alanda eşit şartlara sahip olsa da cinsiyetler arası farkların devam ettiği gözlemlenmektedir. Özellikle spor branşları seçiminde veya müsabakalarda cinsiyet ayrımı gözle görülür şekilde fark edilmektedir. Yarışma sporlarının başarıya ulaşma yolunda içerisinde barındırması gereken özelliklerin güç, fiziksel dayanıklılık ve kararlılık olduğu bilinmektedir. Erkeklerin bu özellikleri taşıdığına hem fikir olan toplum, kadının yarışma sporlarında bulunmasını pek hoş karşılamaz (Yetim, 2006).

\section{Kadının Toplum ve Spordaki Yeri}

Türkiye Cumhuriyeti'nin devamını sağlayacak sıhhatli ve kudretli nesiller yetiştirmek, Cumhuriyetin yegâne hedefidir. Bu sebep ile spor, beden eğitimi, kültürel ve bilimsel bilgiler 
eğitim sistemimizin bir parçası olmuştur (Türkmen, 2012). Modernleşme düşüncesi ile kadınların beden eğitimi ve spora yönlendirilmesi teşvik edilmiştir. Sağlıklı nesiller yetiştirecek olan kadınların beden eğitimi ve spora teşviki sağlanırken çeşitli ideolojiler kullanılmıştır (Koca, 2016). Bu düşünce ile kadın sporcu sayısında artış yakalamak ve kadınların spora adım atmaları hedeflenmiş̧ir. Günümüz kadın sporcularının seçtikleri spor branşları, geçmişteki spor branşlarına göre çeşitlilik göstermektedir. Önceleri kadın sporcuların tercih ettikleri spor branşları daha kadınsı özellikler barındırırken, günümüz kadın spor branşlarında erkeksi özellikler bulunmaktadır. Bir erkek için uygun olduğu düşünülen davranışlara maskülen (erkeksi), kadınlar için uygun olduğu düşünülen davranışlara feminen (kadınsı) denilmektedir. Erkeksi kabul edilen sporlar tehlike, risk, şiddet, hız, dayanıklılık, sabır, meydan okuma ve takım ruhu, cesaret, saldırganlık, gibi özellikler taşır. Bu açıklamaya örnek olarak boks, kayak, hokey, halter verilebilir. Kadınsı sporlar ise zarafet gibi estetik özellikleri bünyesinde barındırır ve aerobik dans, buz pateni, jimnastik, tenis, ata binme ve senkronize yüzme gibi sporlar feminen sporlar olarak değerlendirilebilir (Çetin, 2009).

\section{Sporda Maskülenlik ve Feminenlik}

Methney 1965 'te sporda cinsiyet kavramını ilk olarak tanımlayan araştırmacılardandır. Methney'in spor aktivitelerindeki analizinde, kadın sporlarında algılanan estetik özelliklerin, takım sporları ve doğrudan yarışmalardan çok bireysel aktivitelerde var olduğunu ayrıca vurgulamıştır (Kuzucu Çetin, 2009). Spor branşlarında yapılan birçok inceleme sonucunda sporcuların sahip oldukları cinsiyet rollerinin farklı spor dallarını seçmelerinde etkili olduğu ortaya çıkmıştır. Böylelikle, spor branşlarının erkeksi ve kadınsı olarak algılanması, sporda var olan fiziksel aktiviteler kadar, o spor branşına katılan kişinin cinsiyetinden de etkilenir (Koca, Aşçı ve Kirazcı, 2005). Yapılan çalışma alan yazına katkıda bulunmak, Bursa ilinde 11 ayrı branştaki maskülen spor branşlarıyla ilgilenen kadın sporcuların maskülen branşları seçmelerinin sebeplerini araştırmak ve bu sporcuların cinsiyet rollerinin yaptıkları spor branşına etkilerini incelemek amacıyla yapılmıştır.

\section{YÖNTEM}

\section{Çalışma grubu}

$\mathrm{Bu}$ araştırmanın evreni, Uludağ Üniversitesi Spor Bilimleri Fakültesi Beden Eğitimi ve Spor Öğretmenliği Bölümü ve Antrenörlük Bölümünde okuyan maskülen spor branşlarıyla ilgilenen 18-25 yaş aralı̆ıında bulunan 50kadın sporcu ve kadın futbol takımlarından 3. Lig ve 2. Ligde oynayan 14-25 yaş aralığında bulunan 30 futbolcu ve 14-17 yaş arası 10 kadın taekwondocu olmak üzere toplam 90 kişiden oluşmaktadır.

\section{Veri toplama araçları}

Araştırmada veri toplama aracı olarak araştırmacılar tarafindan hazırlanan kişisel bilgi formu ve BEM (1974) tarafindan geliştirilen "BEM Cinsiyet Rolü Envanteri” ölçeği kullanılmıştır. $\mathrm{Bu}$ araştırmanın verileri, araştırmacı tarafından maskülen spor branşlarıyla ilgilenen kadın sporculara uygulanan anket yoluyla toplanmıştır ve katılımcılara Kişisel Bilgi Formunda; yaş, branş, öğrenim durumu, yetişilen çevre, şu an yaşanılan çevre, kardeş sayısı, ailede kaçıncı 
çocuk olduğu, babanın ve annenin eğitim durumları, ailede sporla ilgilenen başka bireyler olup olmadığı, spora kaç yaşında başlandığı, ilgilenilen spor branşına başlamasında kimlerin etkili olduğu, yapılan spor branşını seçme nedenleri, spora başlama yılı, spora başlandıktan sonra katılımcıların kendilerinde gözlemledikleri özelliklerin neler olduğu? İle ilgili sorular sorulmuştur.

Araştırmada uygulanan ölçek BEM(1974) tarafından geliştirilmiş ve Aşçı ve arkadaşlarının (2004) belirttiğine göre Dökmen tarafından 1991 senesinde geçerlilik ve güvenirlik çalışması yapılmıştır. Ölçeğin iki yarı güvenilirlik katsayısı ise kadınsılık için 0.77, erkeksilik içinse 0.71'dir. Envanterde katılımcılardan kendilerini 7 dereceli bir ölçekte (1: bana göre hiçbir zaman doğru değil, 7: bana göre her zaman doğru) değerlendirmeleri istenmekte, alt ölçeklerde yer alan maddelere verilen yanıtlar ayrı ayrı toplanmaktadır. Bu anketten elde edilen verilerle araştırmanın problemine çözüm aranmıştır. Bunun için önce ilgili alanda literatür taraması yapılmış ve bu konuda yapılmış çalışmalar gözden geçirilmiştir. Veri toplamak için "Anket Survey" tekniği kullanılmıştır. Çalışmanın geçerliliği ve güvenirliliği reliability analysis yöntemi ile yapılmıştır. Araştırmada kullanılan veri toplama aracı kişisel bilgiler dâhil 2 bölümden oluşmaktadır. Araştırmada maskülen spor branşları ile ilgilenen, ragbi branşında 4 , judo branşında 8 , güreş branşında 8 , kick boks branşında 7 , muaythai branşında 4 , taekwondo branşında 17 , hentbol branşında 4 , basketbol branşında 8 , futbol branşında 27 , çekiç atma branşında 1, modern pentatlon branşında 2 kadın sporcu olmak üzere toplam 90 kadın sporcuya 1. Bölüm olan kişisel bilgiler bölümünde bulunan 14 soru, 2 . Bölümde bulunan BEM Cinsiyet Rolü Envanteri kullanılarak 60 soru sorulmuştur. Kişisel bilgiler hariç diğer bölümlerin hepsinde sorulara Kesinlikle Doğru Değil (1), Genellikle Doğru Değil (2), Bazen Doğru (3), Ara Sıra Doğru (4), Çoğunlukla Doğru(5), Genellikle Doğru (6), Her Zaman Doğru(7) şeklinde cevaplar verilmiştir. Öğrencilerden her bir soruya tek cevap vermeleri istenmiştir.

\section{Verilerin istatistiksel analizi}

Veriler SPSS 18.0 paket program kullanılarak analiz edilmiştir. Araştırmaya katılan kadın sporcuların maskülen spor branşlarını tercih etme sebeplerinin incelenmesi ve Bem Cinsiyet Rolü Envanteri arasındaki ilişikler One-Way Anova ve Crosstabs teknikleri kullanılarak analiz edilmiştir.

\section{BULGULAR}

\section{Katılımcıların Demografik Özellikleri}

Çalışmaya 90 kadın sporcu katılıı̧ıtır. Dağılım yüzdeleri; \%4 Ragbi, \%9 Judo, \%9 Güreş, \%8 Kick Boks, \%4 Muay Thai, \%19 Taekwondo, \%4 Hentbol, \%9 Basketbol, \%30 Futbol, \%1 Çekiç Atma, \%2 Modern Pentatlon şeklindedir. Genel dağılımda futbol ve taekwondo sporcuları çoğunluktadır. Toplam 11 branşın 5 tanesi dövüş ve savunma spor branşlarına aittir. Tablo 1' de katılımcı sayılarının değişkenler üzerinde genel dağı̆ımı ile ilgili bilgiler verilmiştir. 
Haşıl-Korkmaz, N., Şen, G. N., Gökduman, Ç., Demir, F., ve Uçar, S.A. (2019). Kadın sporcuların sporu seçme nedenleri. Ulusal Spor Bilimleri Dergisi, 3(1), 14-24.

Tablo 1: Katılımcı sayılarının değişkenler üzerinde genel dağılımı

\begin{tabular}{|c|c|c|}
\hline Öğrenim durumu & Frekans & Yüzde \\
\hline İlköğretim & 5 & $\% 5,6$ \\
\hline Lise & 38 & $\% 42,2$ \\
\hline Üniversite & 45 & $\% 50,0$ \\
\hline Lisansüstü & 2 & $\% 2,2$ \\
\hline Yetiştiği çevre & Frekans & Yüzde \\
\hline Kirsal & 5 & $\% 5,6$ \\
\hline İlçe & 23 & $\% 25,6$ \\
\hline Şehir & 62 & $\% 68,9$ \\
\hline Yurt D1ş1 & 0 & $\% 0$ \\
\hline Şu an yaşadığı çevre & Frekans & Yüzde \\
\hline Kirsal & 3 & $\% 3,3$ \\
\hline İlçe & 16 & $\% 17,8$ \\
\hline Şehir & 71 & $\% 78,9$ \\
\hline Yurt D1ş1 & 0 & $\% 0$ \\
\hline Kaç kardeşsiniz & Frekans & Yüzde \\
\hline Kardeşim yok & 8 & $\% 8,9$ \\
\hline 2 & 40 & $\% 44,4$ \\
\hline 3 & 25 & $\% 27,8$ \\
\hline 4 & 11 & $\% 12,2$ \\
\hline 5 ve üzeri & 6 & $\% 6,7$ \\
\hline Baba eğitim durumu & Frekans & Yüzde \\
\hline İlköğretim & 16 & $\% 17,8$ \\
\hline Ortaokul & 34 & $\% 37,8$ \\
\hline Lise & 27 & $\% 30,0$ \\
\hline Üniversite & 13 & $\% 14,4$ \\
\hline Anne eğitim durumu & Frekans & Yüzde \\
\hline İlkokul & 27 & $\% 30,0$ \\
\hline Ortaokul & 28 & $\% 31,1$ \\
\hline Lise & 25 & $\% 27,8$ \\
\hline Üniversite & 9 & $\% 10,0$ \\
\hline Lisansüstï & 1 & $\% 1,1$ \\
\hline $\begin{array}{l}\text { Spor branşına başlamamda kimler } \\
\text { etkili oldu }\end{array}$ & Frekans & Yüzde \\
\hline Beden eğitimi öğretmenim & 35 & $\% 38,9$ \\
\hline Annem & 12 & $\% 13,3$ \\
\hline Babam & 21 & $\% 23,3$ \\
\hline Arkadaşlarım & 9 & $\% 10,0$ \\
\hline Medya & 2 & $\% 2,2$ \\
\hline Diğer & 11 & $\% 12,2$ \\
\hline $\begin{array}{l}\text { Spora başladıktan sonra kendinizde } \\
\text { ne gibi farklılıklar gözlemlediniz }\end{array}$ & Frekans & Yüzde \\
\hline Özgüvenim arttı & 37 & $\% 41,1$ \\
\hline Kendimi güçlü hissetmeye başladım & 40 & $\% 44,4$ \\
\hline Erkeksi hissetmeye başladım & 5 & $\% 5,6$ \\
\hline Erkeksi davranışlarım çoğald 1 & 3 & $\% 3,3$ \\
\hline Bir farklılık yaşamadım & 5 & $\% 5,6$ \\
\hline $\begin{array}{l}\text { Yaptığınız spor branşını seçme } \\
\text { nedeni? }\end{array}$ & Frekans & Yüzde \\
\hline Sağlıklı olmak & 3 & $\% 3,3$ \\
\hline Sosyal çevre edinmek & 8 & $\% 8,9$ \\
\hline Milli sporcu olmak & 27 & $\% 30,0$ \\
\hline Para kazanmak & 5 & $\% 5,6$ \\
\hline Kendi benliğimi bulmak & 33 & $\% 36,7$ \\
\hline Diğer & 14 & $\% 15,6$ \\
\hline $\begin{array}{l}\text { Ailenizde sporla uğraşan biri var } \\
\text { mı? }\end{array}$ & Frekans & Yüzde \\
\hline Babam & 16 & $\% 17,8$ \\
\hline Annem & 5 & $\% 5,6$ \\
\hline Kardeşim & 20 & $\% 22,2$ \\
\hline Yakın akrabam & 16 & $\% 17,8$ \\
\hline Sporla uğraşan yok & 33 & $\% 36,7$ \\
\hline Toplam & 90 & $\% 100$ \\
\hline
\end{tabular}

Tablo 1'de değişkenler üzerinde katılımcı sayılarının genel dağılımı görülmektedir. Katılımcıların "Öğrenim Durumu” \%50 Üniversite, \%42 Lise, \%6 İlköğretim, \%7 Lisansüstü şeklinde yüzdelik dağılım göstermektedir. Katılımcıların "Yetiştiği Çevre" yüzdeleri \%69 Şehir, \%25 İlçe, \%6 Kırsal, \%0 Yurt Dışı şeklindedir. Katılımcıların "Şuan Yaşadığı Çevre” 
değişkenine bakıldığında \%79 Şehir, \%26 İlçe, \%3 Kırsal, \%0 Yurt Dışı yüzdeliklerine sahiptir. Katılımcıların "Kaç Kardeşsiniz" sorusuna verdikleri cevaplara bakıldığında kardeş sayıs1 2 olanlar \%44, kardeş sayısı 3 olanlar \%28, kardeş sayısı 4 olanlar \%12, kardeşi olmayanlar $\% 8$, kardeş sayısı 5 ve üzeri olanlar ise $\% 7$ şeklinde yüzdelik dağılım göstermektedir. Katılımcıların "Baba Eğitim Durumu" yüzdeleri \%38 Ortaokul, \%30 Lise, \%18 İlköğretim, \%15 Üniversite şeklindedir. "Anne Eğitim Durumu” ise \%31 Ortaokul, \%30 İlkokul, \%28 Lise, \%10 Üniversite, \%1 Lisansüstü şeklinde yüzdelik dağılım göstermektedir. Katılımcılar "Spora Başlamanızda Kimler Etkili Oldu" sorusuna verdikleri cevap yüzdelikleri ise \%39 Beden Eğitimi Öğretmenim, \%23 Babam, \%13 Annem, \%12 Diğer, \%10 Arkadaşlarım, \%2 Medya şeklindedir. Katılımcıların "Spora Başladıktan Sonra Kendinizde Ne Gibi Farkl11ıklar Gözlemlediniz? Sorusuna \%44 Kendimi güçlü hissetmeye başladım, \%41 Özgüvenim Arttı, \%5 Erkeksi Hissetmeye Başladım, \%5 Bir Farklılık Yaşamadım, \%3 Davranışlarım Çoğalmaya Başladı yüzdelik dağılım şeklinde cevaplar verildiği görülmektedir. Katılımcılar "Yaptı̆ı̆ını Spor Branşını Seçme Nedeniniz?" Sorusuna \%36 Kendi Benliğimi Bulmak, \%30 Milli Sporcu olmak, \%15 Diğer, \%9 Sosyal Çevre Edinmek, \%6 Para Kazanmak, \%3 Sağlıklı Olmak şeklinde yüzdelikler dağılımında cevap vermişlerdir. Katılımcılar "Ailenizde sporla uğraşan biri var mı?” sorusuna \%37 Sporla Uğraşan Yok, \%22 Kardeşim, \%18 Yakın akrabam, \%18 Babam, \%6 Annem yüzdeliklere dağılım şeklinde cevap verildiği görülmektedir.

Tablo 2: Yaş Durumu ve Spora Başladıktan Sonra Kendinizde Ne Gibi Farklar Gözlemlediniz? Değişkenlerine Göre Dağılım

\begin{tabular}{|c|c|c|c|c|c|c|}
\hline $\begin{array}{c}\text { Yaş } \\
\text { Durumu }\end{array}$ & $\begin{array}{c}\text { Özgüvenim } \\
\text { Arttı }\end{array}$ & $\begin{array}{c}\text { Kendimi Güçlü } \\
\text { Hissetmeye } \\
\text { Başladım } \\
\end{array}$ & $\begin{array}{c}\text { Erkeksi } \\
\text { Hissetmeye } \\
\text { Başladım } \\
\end{array}$ & $\begin{array}{c}\text { Erkeksi } \\
\text { Davranışlarım } \\
\text { Çoğaldı } \\
\end{array}$ & $\begin{array}{c}\text { Bir } \\
\text { Farklılık } \\
\text { Yaşamadım } \\
\end{array}$ & Toplam \\
\hline \multirow{3}{*}{$14-17$} & 12 & 24 & 5 & 2 & 1 & 44 \\
\hline & $27,30 \%$ & $54,50 \%$ & $11,40 \%$ & $4,50 \%$ & $2,30 \%$ & $100,00 \%$ \\
\hline & $32,40 \%$ & $60,00 \%$ & $100,00 \%$ & $66,70 \%$ & $20,00 \%$ & $48,90 \%$ \\
\hline \multirow{3}{*}{$18-21$} & 16 & 11 & 0 & 1 & 3 & 31 \\
\hline & $51,60 \%$ & $35,50 \%$ & $0,00 \%$ & $3,20 \%$ & $9,70 \%$ & $100,00 \%$ \\
\hline & $43,20 \%$ & $27,50 \%$ & $0,00 \%$ & $33,30 \%$ & $60,00 \%$ & $34,40 \%$ \\
\hline \multirow{3}{*}{$22-25$} & 8 & 5 & 0 & 0 & 1 & 14 \\
\hline & $57,10 \%$ & $35,70 \%$ & $0,00 \%$ & $0,00 \%$ & $7,10 \%$ & $100,00 \%$ \\
\hline & $21,60 \%$ & $12,50 \%$ & $0,00 \%$ & $0,00 \%$ & $20,00 \%$ & $15,60 \%$ \\
\hline \multirow{3}{*}{ Toplam } & 37 & 40 & 5 & 3 & 5 & 90 \\
\hline & $41,10 \%$ & $44,40 \%$ & $5,60 \%$ & $3,30 \%$ & $5,60 \%$ & $100,00 \%$ \\
\hline & $100,00 \%$ & $100,00 \%$ & $100,00 \%$ & $100,00 \%$ & $100,00 \%$ & $100,00 \%$ \\
\hline
\end{tabular}

Tablo 2'de 14-17 yaş grubu toplam katılım sayısı 44 kişidir. $\mathrm{Bu}$ yaş grubunun verdiği cevaplarda "Kendimi Güçlü Hissetmeye Başladım" değişkenine \%55 katılım olduğu görülmektedir. Aynı zamanda 14-17 yaş grubunda \% 27 "Özgüvenim Arttı", \%11 "Kendimi Erkeksi Hissetmeye Başladım", \%5 "Erkeksi Davranışlarım Çoğaldı", \%2 "Bir Farklılık Yaşamadım" şeklinde dağılım görülmektedir.18-21 yaş grubu genel katılım sayısı 31 kişidir. Bu yaş grubunun verdiği cevaplarda "Özgüvenim Arttı" \% 52, "Kendimi Güçlü Hissetmeye Başladım" \%36, "Bir farklılık yaşamadım" \%10, "Erkeksi davranışlarım çoğaldı" \%3", "Kendimi Erkeksi Hissetmeye Başladım" \%0şeklinde dağılım görülmektedir. 22-25 yaş grubu genel katılım sayısı 14 kişidir. Bu yaş grubunun verdiği cevaplar da "Özgüvenim Arttı" \% 57, 
"Kendimi Güçlü Hissetmeye Başladım” \%36, "Bir farklılık yaşamadım” \%7, "Erkeksi Davranışlarım Çoğaldı" \%0, "Kendimi Erkeksi Hissetmeye Başladım” \%0 şeklinde dağılım görülmektedir.

Tablo 3:Yaş Durumu ve Erkeksi Değişkenine Göre Dağılım

\begin{tabular}{ccccccccc}
\hline $\begin{array}{c}\text { Yaş } \\
\text { Durumu }\end{array}$ & $\begin{array}{c}\text { Kesinlikle } \\
\text { Doğru } \\
\text { Değil }\end{array}$ & $\begin{array}{c}\text { Genellikle } \\
\text { Doğru Değil }\end{array}$ & $\begin{array}{c}\text { Bazen } \\
\text { Doğru }\end{array}$ & $\begin{array}{c}\text { Ara } \\
\text { Sira } \\
\text { Doğru }\end{array}$ & $\begin{array}{c}\text { Çoğunlukla } \\
\text { Doğru }\end{array}$ & $\begin{array}{c}\text { Genellikle } \\
\text { Doğru }\end{array}$ & $\begin{array}{c}\text { Her } \\
\text { Zaman } \\
\text { Doğru }\end{array}$ & Toplam \\
\hline $\mathbf{1 4 - 1 7}$ & 11 & 8 & 2 & 4 & 5 & 4 & 10 & 44 \\
& $25,00 \%$ & $18,20 \%$ & $4,50 \%$ & $9,10 \%$ & $11,40 \%$ & $9,10 \%$ & $22,70 \%$ & $100,00 \%$ \\
\hline $\mathbf{1 8 - 2 1}$ & 15 & 4 & 5 & 2 & 0 & 1 & 4 & 31 \\
\cline { 2 - 9 } & $48,40 \%$ & $12,90 \%$ & $16,10 \%$ & $6,50 \%$ & $0,00 \%$ & $3,20 \%$ & $12,90 \%$ & $100,00 \%$ \\
\hline $\mathbf{2 2 - 2 5}$ & 3 & 4 & 3 & 4 & 0 & 0 & 0 & 14 \\
\cline { 2 - 9 } & $21,40 \%$ & $28,60 \%$ & $21,40 \%$ & $28,60 \%$ & $0,00 \%$ & $0,00 \%$ & $0,00 \%$ & $100,00 \%$ \\
\hline \multirow{2}{*}{ Toplam } & 30 & 16 & 10 & 10 & 5 & 5 & 14 & 90 \\
\cline { 2 - 9 } & $33,30 \%$ & $17,80 \%$ & $11,10 \%$ & $11,10 \%$ & $5,60 \%$ & $5,60 \%$ & $15,60 \%$ & $100,00 \%$ \\
\hline
\end{tabular}

Tablo 3'te 14-17 yaş grubu toplam katılımı 44 kişidir. Bu yaş grubunda "Kesinlikle Doğru Değil" \%25, "Genellikle Doğru Değil” \%18, "Bazen Doğru” \%5, Ara S1ra Doğru \%9, "Çoğunlukla Doğru” \%11, "Genellikle Doğru” \%9, "Her Zaman Doğru” \%23 şeklinde katılım sağlamıştır. Bu durum 18-21 yaş grubundaki katılımcılara bakıldığında "Kesinlikle Doğru Değil” \%48, "Genellikle Doğru Değil” \%13, "Bazen Doğru” \%16, Ara Sıra Doğru \%7, "Çoğunlukla Doğru” \%0, "Genellikle Doğru” \%3, "Her Zaman Doğru” \%13 şeklinde katılım sağlamışlardır. 22-25 yaş grubunda ise "Kesinlikle Doğru Değil” \%21, "Genellikle Doğru Değil" \%29, "Bazen Doğru” \%21, Ara Sıra Doğru \%29, "Çoğunlukla Doğru" \%0, "Genellikle Doğru" \%0, "Her Zaman Doğru” \% 0, şeklinde katılım sağlandığı görülmektedir

Tablo 4: Katılımcıların Spora Başlamanızda Kimler Etkili Oldu? Değişkenine Göre BEM Cinsiyet Rolü Puanı

\begin{tabular}{|c|c|c|c|c|c|c|}
\hline & & $\mathbf{N}$ & $\mathbf{X}$ & $\mathbf{S S}$ & $\mathbf{F}$ & $\mathbf{P}$ \\
\hline \multirow{10}{*}{ Kadınsı } & Beden eğitimi öğretmenim & 35 & 101,657 & 12,527 & \multirow{7}{*}{1,468} & \multirow{7}{*}{0,209} \\
\hline & Annem & 12 & 105,916 & 11,602 & & \\
\hline & Babam & 21 & 99,809 & 16,913 & & \\
\hline & Arkadaşlarım & 9 & 105,555 & 9,514 & & \\
\hline & Medya & 2 & 88 & 19,798 & & \\
\hline & Diğer & 11 & 110,272 & 17,765 & & \\
\hline & Toplam & 90 & 102,933 & 14,331 & & \\
\hline & Beden eğitimi öğretmenim & 35 & 101,628 & 17,54 & \multirow{7}{*}{3,257} & \multirow{7}{*}{0,01} \\
\hline & Annem & 12 & 116,083 & 10,816 & & \\
\hline & Babam & 21 & 100 & 14,474 & & \\
\hline \multirow{7}{*}{ Erkeksi } & Arkadaşlarım & 9 & 111,777 & 12,204 & & \\
\hline & Medya & 2 & 115,5 & 9,192 & & \\
\hline & Diğer & 11 & 112,727 & 12,116 & & \\
\hline & Toplam & 90 & 105,855 & 15,83 & & \\
\hline & Beden eğitimi öğretmenim & 35 & 87,2286 & 9,261 & \multirow{7}{*}{1,686} & \multirow{7}{*}{0,147} \\
\hline & Annem & 12 & 96,75 & 28,113 & & \\
\hline & Babam & 21 & 87,1429 & 11,046 & & \\
\hline \multirow{4}{*}{ Nötr } & Arkadaşlarım & 9 & 89,6667 & 13,738 & & \\
\hline & Medya & 2 & 97,5 & 9,192 & & \\
\hline & Diğer & 11 & 98,0909 & 15,578 & & \\
\hline & Toplam & 90 & 90,2778 & 14,947 & & \\
\hline
\end{tabular}


Tablo 4'te katılımcıların spora başlamasında etkili olan kişilerin cinsiyet rolleri üzerinde etkileri karşılaştırıldığında erkeksi grubunda anlamlı bir fark olduğu görülmektedir. Gruplandırılan erkeksi cinsiyet rolüne sahip katılımcıların spora başlamasında etkili olan kişiler karşılaştırıldığında, en yüksek ortalamanın erkeksi grubundaki katılımcıların annelerine $(X=116,083)$ ait olduğu görülmektedir. Erkeksi grubunun içinde en düşük ortalama ise babalarına $(X=100,000)$ ait olduğu görülmektedir. Katılımcıların spora başlamasında etkili olan kişilerin cinsiyet rolleri üzerindeki etkilerinin farklılaşıp farklılaşmadığını test etmek amacıyla Tek Yönlü Varyans (One-Way ANOVA) analizi kullanılmıştır.

\section{TARTIŞMA ve SONUÇ}

$\mathrm{Bu}$ bölümde araştırma sonucunda elde edilen bulgulara dayalı olarak tartışmalara yer verilmiştir.

Göktaş (1994), yaptığı araştırmada; öğrencilerin sosyo-ekonomik yapısındaki farklılıkların, ilgilenilen spor dalının seçiminde ve spor yapılmasındaki amacın tespitinde önemli bir etkiye sahip olduğunu ortaya çıkarmıştır. Ayrıca öğrencilerin spor yapmalarında en önemli amacın ilk olarak ülkeyi en iyi şekilde temsil etmek ve sporda başarılı olmak daha sonra sırasıyla sağliklı bir yaşam, çevreye kendini kabul ettirme gibi faktörlerinin etkili olduğu ortaya çıkmıştır. Alibaz ve ark.,'nın (2006), “Türkiye'de Üst Düzey Taekwondo, Karate ve KickBoks Sporcularının Bu Spor Branşına Yönelmelerine Teşvik Eden Unsurlar, Yapma Nedenleri ve Geleceğe Yönelik Beklentileri” üzerine birlikte yaptıkları çalışma sonucunda; bu sporlara yönelme nedenleri olarak antrenör ve ailenin yüksek düzeyde etkisinin olduğunu belirlemişlerdir. Ayrıca Türkiye'de Taekwondo, Karate ve Kick-Boks sporuyla uğraşma nedeni olarak yaptıkları spor branşını sevmek ve başarı kazanmaktan haz duymanın etkili olduğu saptanmıştır. Öte yandan sporcuların, ilgili spor branşlarını devam ettirmek suretiyle milli takıma seçilmek, milli sporcu olmak ve sağlıklı bir yaşam sürdürebilmek beklentilerinde oldukları belirlenmiştir.

"Kadın Sporcuların Sporu Seçme Nedenleri” adlı çalışmada elde edilen sonuçların Göktaş (1994)'ın Çalışması ile benzerlik gösterdiği belirlenmiştir. 14-17 yaş grubunda bulunan kadın sporcuların sporu tercih etme nedenlerinde "Milli Sporcu Olmak" değişkeni çoğunluk göstermektedir.

Yıldız (2006), "Ortaöğretim Kurumları Spor Alanında Okuyan Öğrencilerin Spora Başlama ve Alanı Seçme Nedenleri İle Beklentileri” üzerine yaptığı çalışma sonucunda; öğrencilerin spor alanına yönelme nedenlerinin, ders çalışmayı sevmediklerinden dolayı değil en önemli faktörün özellikle aktif sporcu olmalarının ve sporu sevmelerinden dolayı olduğunu belirtmiştir. Bununla beraber spora başlamada ailenin çok büyük etkisi ve önemi olduğu, arkadaş çevresinin ve öğretmenlerinin daha az etkisi olduğu görülmüştür. Öğrencilerin büyük bir kısmının hayatlarını sporcu olarak devam ettirmek istedikleri tespit edilmiştir. Benzer olarak, Whitehead ve ark., (2006), "Fiziksel Aktivite Seviyeleri Farklı Gruplardaki SosyoPsikolojik ve Fiziksel Çevre Faktörler" adlı çalışmaları sonucunda da İskoç genç kız 
sporcularının spora yönelmelerinde fiziksel çevre ve annelerinin katkısının fazla olduğunu saptamışlardır. "Kadın Sporcuların Sporu Seçme Nedenleri” adlı yapılan çalı̧̧mada varılan sonuçlarda da aile fertlerinin spora başlamalarındaki etkililiği söz konusudur. Özellikle ailede annenin spor branşı ile ilgilenmesi ve çocuklarının spora başlamasında etkili olduğu sonucuna ulaşılmıştır.

Kavasoğlu ve Yaşar (2016),“Toplumsal Cinsiyet Normlarının Dışındaki Sporcular” üzerine birlikte yaptıkları çalışmada sporcuların, cinsiyet normları ile uyuşmayan spor dallarında, toplumsal cinsiyet baskısını nasıl algıladıklarını ve neler deneyimlediklerini belirlemişlerdir. Ayrıca "Kadın Sporcuların Sporu Seçme Nedenleri" adlı çalışmamızda nicel araştırma yöntemi kullanılmıştır. Çalışmamızdan farklı olarak "Toplumsal Cinsiyet Normlarının Dışındaki Sporcular" çalışmasında nitel araştırma yöntemi fenomenoloji tekniği kullanılmıştır. "Kadın Sporcuların Sporu Seçme Nedenleri” adlı çalışmamızın evren örneklem grubunu sadece kadın sporcular oluşturmaktadır. Çalışmamızdan farklı olarak "Toplumsal Cinsiyet Normlarının Dışındaki Sporcular" adlı çalışmanın evren örneklem grubunu 5 kadın ve 5 erkek sporcu oluşmaktadır. Çalışmanın sonucunda birebir görüşme ile her iki cinsiyette sporcuların normların dışındaki spor dallarında olmaları nedeniyle baskı, engelleme ve ayrımcılık yaşamaları sonucuna ulaşılmıştır. "Kadın Sporcuların Sporu Seçme Nedenleri”" adlı çalışmamızda birebir görüşme tekniği kullanılsaydı benzer sonuçlara varılabilirdi.

Bem cinsiyet rolü envanteri puanları "Baba Eğitim Durumu" değişkenine göre erkeksi özelliklere sahip katılımcıların babalarının eğitim durumunun (üniversite) yüksek olduğu sonucuna ulaşılmıştır. Spor branşına başlamalarında etkili olan kişilere göre erkeksi özelliklere sahip olan katılımcıların spor branşına başlamalarında aile bireyleri içerisinde annelerinin etkili olduğu sonucuna ulaşılmışır. Ayrıca ailelerinde sporla uğraşan kişiler değişkenine göre katılımcıların annelerinin puanlarının diğer aile bireylerine göre yüksek olduğu sonucuna ulaşılmıştır.

Yapılan karşılaştırmalar sonucunda "Yaş Durumu İle Spora Branşına Başlama Nedenleri" karşılaştırıldığında ise 14-17 yaş aralığındaki sporcular öncelikle milli sporcu olmayı neden olarak gösterdikleri sonucuna ulaşılmaktadır. 18-21 ve 22-25 yaş aralıklarındaki sporcularda ise spora başlama nedenleri olarak kendi benliğini bulmak değişkenini neden olarak gösterdikleri sonucuna ulaşılmıştır. Yapılan karşılaştırmalar sonucunda yaş durumu ile "Spora başladıktan sonra kendinizde ne gibi farklılıklar gözlemlediniz" değişkeni karşılaştırıldığında tüm yaş grubundaki sporcuların ortak olarak özgüvenlerinin arttı̆̆ ve kendilerini güçlü hissetmeye başladıkları cevaplarına katıldıkları sonucuna ulaşılmışıı. Bu değişken içerisinde erkeksi hissetmeye başladım ve erkeksi davranışlarım çoğaldı değişkenlerinde katılımcıların yaşları arttıkça bu iki seçeneğe katılan sporcuların sayılarında azalma olduğu sonucuna ulaşılmıştır. Yapılan karşılaştırma sonucunda katılımcıların erkeksi değişkenine katılma oranları yaşları büyüdükçe azaldığı sonucuna ulaşılmışırı. 
Ulaşılan genel sonuçlar ışı̆̆ında aşağıdaki öneriler geliştirilebilir:

Spor, cinsiyet ayrımcılığının ve toplumsal cinsiyet kalıp yargılarının kırılmasına imkân sağlayacak en elverişli yollardan biridir. Nitekim erkeklerin yoğunlukta olduğu spor dallarında kadın sporcular, kadınların yoğunlukta olduğu spor dallarında erkek sporcular toplumun zihinsel dönüşümüne aracılık edebilecek roldedirler.

$\mathrm{Bu}$ spor dallarında azınlıkta olan sporcuların sayısı ve toplumsal kabulü arttıkça, onlara yönelik oluşturulan toplumsal cinsiyet baskısı azalacaktır. Toplumsal cinsiyet eşitsizliğinin şimdilik tamamen yok edilmese de hafifletilmesinde bu sporcuların büyük katkılarının olacağ düşünülmektedir.

Spor yöneticilerinin ve antrenör, sporcu, hakem, beden eğitimi öğretmeni vb. gibi spor alanındaki tüm aktörlerin toplumsal cinsiyet eşitsizliğini önleyecek çözümler üretmesi beklenmekte ve yapılacak bilgilendirmeler neticesinde hem spor camiasına hem de topluma büyük katkılar sağlayacağı düşünülmektedir.

\section{KAYNAKLAR}

Alibaz, A., Gündüz, N., ve Şentuna, M. (2006). Türkiye'de üst düzey taekwondo, karate ve kick-boks sporcularının bu spor branşına yönelmelerine teşvik eden unsurlar, yapma nedenleri ve geleceğe yönelik beklentileri. Spormetre Beden Eğitimi ve Spor Bilimleri Dergisi, 4(2), 91.

Aşçı, F.H., Kirazcı, S. ve Koca, C. (2004). Takım ve bireysel sporlarla uğraşan kadın ve erkek sporcuların ve sporcu olmayanların toplumsal cinsiyet rol eğilimi. Gazi Beden Ĕ̈itimi ve Spor Bilimleri Dergisi, IX(2004)2, 3-10.

Çetin, B. (2009). Feminen ve maskülen spor yapan kadınlarda fiziksel benlik algısı. Yüksek Lisans Tezi, Mersin Üniversitesi Sağlık Bilimleri Enstitüsü Beden Eğitimi ve Spor Anabilim Dalı, Mersin.

Direk, Z. (2014). Cinsiyetli olmak. 4. Bask1, ss. 86-90, İstanbul: Yap1 Kredi Yayınları.

Dökmen, Z. (2004). Toplumsal Cinsiyet. ss.100-180, Ankara: Sistem Yayınc1lık.

Göktaş, Z.(1994). Farklı sosyo-ekonomik yapıdaki ortaöğretim kurumlarında okuyan öğrencilerin spora katılımına etki eden faktörler. Yüksek Lisans Tezi, Gazi Üniversitesi, Sağlık Bilimleri Enstitüsü, Beden Eğitimi ve Spor Anabilim Dalı, Ankara.

Göktepe, M. (2008). Türkiye'deki bayan futbolcuların sosyo-ekonomik durumları ve futbol branşına yönelme nedenleri. Yüksek Lisans Tezi, Gazi Üniversitesi Eğitim Bilimleri Enstitüsü Beden Eğitimi ve Spor Öğretmenliği Anabilim Dalı, Ankara.

Kavuncu, A.N. (1987). BEM Cinsiyet rolü envanterinin Türk toplumuna uyarlamast. Yüksek Lisans Tezi, Hacettepe Üniversitesi Sosyal Bilimler Enstitüsü, Ankara.

Koca, C., Asci, H. ve Kirazci, S. (2005). Gender role orientation of athletes and nonathletes in a patriarchal society. Woman in Sport And Physical Activity Journal, 14(1), 86-94.

Koca, C. (Editör). (2016). Sporun toplumsal cinsiyet halleri. 1. Bask1, ss. 20-60, Ankara: Spor Yayınevi. 
Haşıl-Korkmaz, N., Şen, G. N., Gökduman, Ç., Demir, F., ve Uçar, S.A. (2019). Kadın sporcuların sporu seçme nedenleri. Ulusal Spor Bilimleri Dergisi, 3(1), 14-24.

Kuzucu Çetin, B. (2009). Feminen ve maskülen spor yapan kadınlarda fiziksel benlik algısı. Yüksek Lisans Tezi, Mersin Üniversitesi Sağlık Bilimleri Enstitüsü Beden Eğitimi ve Spor Anabilim Dalı, Mersin.

Şirvanl1-Özan, D., ve Bayraktar, R. (1993). Annenin çalışma durumunun çocuğun cinsiyet özelliklerine ilişkin kalıp yargllarının gelişim üzerindeki rolü, VII. Ulusal Psikoloji Kongresi bilimsel çalışmaları, ss.65-76, Ankara: Meteksan.

Türkmen, M. (2012), Siyasal Toplumsallaşma Aracı Olarak Beden Eğitimim ve Spor; İşçi Sporları ve Türkiye'deki Etkileri (1923-1938). Yayımlanmamış Doktora Tezi. Gazi Üniversitesi, Ankara.

Whitehed, S.H., Biddle, J.H., O’donovan, T.M. andNevill, M.E. (2006). Social Psychological and Physical Environmental Factors in Groups Differing by Levels of Physical Activity: A Study of Scottish Adolescent Girls. Pediatric Exercise Science, 18, 2, 226-239.

Yetim, A.A. (2006), Sosyoloji ve Spor, İstanbul: Morpa Kültür Yayınları.

Yıldız, G.H. (2006). Ortaöğretim Kurumları Spor Alanında Okuyan Öğrencilerin Spora Başlama ve Bu Alanı Seçme Nedenleri İle Beklentileri (Ankara İli Örneği). (Yüksek Lisans Tezi) Gazi Üniversitesi Eğitim Bilimleri Enstitüsü Beden Eğitimi ve Spor Öğretmenliği Anabilim Dalı. Ankara. 